\title{
THE TURNOVER INTENTIONS FOR CONSTRUCTION ENGINEERS
}

Kuo-Shun Sun

Department of Air Transportation, Kainan University, Taoyuan County, Taiwan, R.O.C., kssun@mail.knu.edu.tw

Follow this and additional works at: https://jmstt.ntou.edu.tw/journal

Part of the Business Analytics Commons

\section{Recommended Citation}

Sun, Kuo-Shun (2011) "THE TURNOVER INTENTIONS FOR CONSTRUCTION ENGINEERS," Journal of Marine Science and Technology. Vol. 19: Iss. 5, Article 11.

DOI: $10.51400 / 2709-6998.2169$

Available at: https://jmstt.ntou.edu.tw/journal/vol19/iss5/11

This Research Article is brought to you for free and open access by Journal of Marine Science and Technology. It has been accepted for inclusion in Journal of Marine Science and Technology by an authorized editor of Journal of Marine Science and Technology. 


\title{
THE TURNOVER INTENTIONS FOR CONSTRUCTION ENGINEERS
}

\author{
Kuo-Shun Sun*
}

Key words: job satisfaction, organizational commitment, labor turnover intention, engineers.

\begin{abstract}
This study looks at the effects of job satisfaction, organizational commitment and individual factors on turnover intentions of construction engineers. It makes use of samples of the construction engineers from the engineering design department of Taiwanese engineering consultant companies. From the results of a logistic regression analysis, normative commitment as well as job satisfaction were found to significantly impact construction engineers' turnover intentions.
\end{abstract}

\section{INTRODUCTION}

There are a lot of infrastructure and construction projects, like airports, harbors, bridges, tunnels, roadwork, and buildings, etc., to be undertaken to meet the requirements of the development of the country. The technical and contractual intricacy of today's infrastructure and construction projects necessitates the appointment of competent Engineering Consultants (ECs) to preserve the rights and interests of the client $[23,26,40,51]$. The duties undertaken by an engineering consultant company would typically include preliminary and feasibility studies, drawing up all detail plans, designs, specifications, forms of tender and conditions of contract for the work and possibly supervising the work of an appointed contractor. Consulting engineering firms employ professional engineers to offer services in engineering skills and knowledge. Firms usually work on a project-by-project basis but repeat clients are common. Usually smaller firms specialize in a single engineering discipline (e.g. structural, civil, mechanical, electrical, industrial) whereas the larger firms offer multi-disciplinary services [86].

In essence, what the consulting engineer does is place at the disposal of a client, on the basis of mutual trust, their technical knowledge, experience and ability, bound by a duty to safe-

Paper submitted 03/23/10; revised 07/06/10; accepted 07/16/10. Author for correspondence: Kuo-Shun Sun (e-mail: kssun@mail.knu.edu.tw).

*Department of Air Transportation, Kainan University, Taoyuan County, Taiwan, R.O.C. guard the client's interest while ensuring a sound engineering job at a minimum whole life cost $[9,73]$.

The construction industry faces many challenges. Many of these challenges arise through a need to maintain the skills and competitive workforce [83]. The cost of turnover to organizations can be high [22]. Given the knowledge-intensive nature of the construction industry and its relatively high labor costs in overall costs, turnover is an important issue for the engineering consultant industry. Construction engineers serving as knowledge employees play a critical role in directly delivering engineering quality as well as safety to owners. The engineering consultant companies in general invest significant resources in the recruiting, selecting and training of their construction engineers, seeking to maximize the quality of engineering service delivery.

Due to high work stress and an unstable working environment, the turnover of construction engineers is an important issue from a practical viewpoint. Surprisingly, however, this subject has tended to be neglected. Among various antecedents, job satisfaction and organizational commitment appear to be good predictors of turnover rates and these are the factors investigated here, together with the individual characteristics of construction engineers.

\section{PREVIOUS WORK}

\section{Job Satisfaction}

Employees' job satisfaction is an important facet of human resource management (HRM) [1]. Job satisfaction can be conceived as an overall rating or as the sum of several discrete dimensions of job characteristics [71, 92, 95]. Job satisfaction may be defined as a pleasant or positive emotional state resulting from the satisfactory appraisal of one's job or job experiences [58] or the degree of positive affects towards a job or its components, whereas the key attitude relates to employee behaviors, such as job performance and turnover [22]. In other words, job satisfaction represents an effective response to specific aspects of the job. This is determined by characteristics both of the individual and of the job and particularly how work is organized within the corporate work environment. Many research studies on the job satisfaction of construction workers were performed in the 1980s. Borcherding and Oglesby [17] studied the relationship between job satisfaction and construction productivity by in-depth interviews, but it 
was not based on empirical evidence and thus the validity of some of their findings were questioned [31]. Bowen, et al. [18] takes an empirical study of Job satisfaction of South African quantity surveyors by web-based national questionnaire. Shore and Martin [91] reported that high job satisfaction leads to a high level of commitment among professionals. Huang, et al. [47] (2007) dissected engineers were more likely to have lower job satisfaction under higher time-control or overall job stress.

\section{Organizational Commitment}

There are many definitions about organizational commitment. Organizational commitment represents how employees feel toward the company or organization. In other words, organizational commitment is an effective response to the whole organization [100]. Organizational commitment is the strength of an individual's identification with and involvement in an organization [79]. Porter [76] saw it as the willingness of an employee to exert high levels of effort on behalf of the organization, a strong desire to stay with the organization and acceptance of its major goals and values. Sheldon [90] viewed it as a positive evaluation of the organization and the intention to work toward its goal. Kantor [50] defined it as the willingness of social actors to give energy and loyalty to the organization. Hrebiniak and Allutto [46] considered it the unwillingness to leave the organization for increased pay, status, or professional freedom or for greater friendship between colleagues. Buchanan [20] employed it as a partisan, affective attachment to the goals and values of an organization, to one's role in relation to goals and values and to the organization for its own sake, apart from its purely instrumental worth. Organizational commitment has been consistently linked with positive organizational outcomes, such as reduced turnover and absenteeism and higher motivation and productivity [66]. Analytical techniques including factor analysis, correlation coefficients and regression analysis and structural equation modeling were applied by Leung and Chan [56] to investigate the relationships among the factors of commitment in the construction industry in Hong Kong and three forms of commitment were discovered and named Affective commitment, Continuous commitment and Normative commitment.

\section{Turnover Model}

Interest in explaining employee turnover has long been a major concern of organizational scholars $[27,59,80]$. Turnover is represented as the degree of individuals to quit the membership of a social system (e.g., a company) [15]. Turnover intention was conceived to be a conscious and deliberate willingness to leave the organization [94]. Recently the literatures on turnover have become voluminous and studies may be categorized as two types [80]. First, there are the literatures that explicitly indentify turnover as the dependent variable to be explained $[14,19,21,25,33,34,53,55,64,74,75,78,88$, $89,93]$. Second, there are studies that treat turnover as a component of some more general phenomenon or depict it as but one of several dependent variables to be explained [6, 52, 54, $60,62,96]$. Over the last 30 years, most research devoted to predictive turnover intention has included individual job dissatisfaction as a primary catalyst for turnover $[61,82,94]$. On the other hand, Organizational commitment is also a consistent predictor of employee turnover [37, 49, 94] among the most commonly proposed antecedents.

Individual studies have generally supported hypothesized links between turnover intention and those variables [94]. Job satisfaction and organizational commitment have invariably been reported to be negatively related to intent to leave $[7,43]$ and positively correlated with one another [16, 24, 32]. In terms of their relative contributions to the turnover process, there are three main theoretical perspectives $[79,94]$. There are the satisfaction-to-commitment-mediation model $[16,63$, $69,79,81,100]$, the commitment-to-satisfaction-mediation model $[11,13,72,77,85,87]$ and the independent-effects model $[3,57,68,97]$.

The satisfaction-to-commitment-mediation model postulates that organizational commitment develops from job satisfaction, such that commitment mediates the effects of satisfaction on turnover variables. The commitment-to-satisfaction-mediation model posits that organizational commitment engenders a positive attitude toward the job and employee's turnover behavior depends upon the employee job satisfaction level. The independent-effects model holds that both job satisfaction and organizational commitment contribute independently to the turnover process. It hypothesizes that job satisfaction and organizational commitment, though related, are distinct constructs implying no particular causality relationship between them.

In addition to job satisfaction and organizational commitment, several factors have been also used to examine their contributions to turnover [99]. These factors include personal and work environment characteristics such as age, gender, education and organizational tenure. For exploratory purposes, this study adopts the independent-effects model and incorporates employees' individual characteristics to investigate their relative impacts on turnover intentions.

\section{RESEARCH METHOD}

\section{Measures}

Given the considerable evidence that professional turnover might be influenced by personnel characteristics, job satisfaction and organization commitment, research was undertaken to explore this issue. To facilitate the study objective and to ensure reliability and validity in the research results, a questionnaire consisting of four parts was used to examine influences on construction engineer turnover.

Part 1 deals with the measurement of job satisfaction using 20 items based on the Minnesota Satisfaction Questionnaire (MSQ) short form developed by Weiss et al. [98]. The survey instrument is widely used in research on job satisfaction $[8,12$, $39,41,65]$. 
Part 2 deals with the measurement of organizational commitment using 20 items from Mowday et al.'s. [70] Organizational Commitment Questionnaire (OCQ).

Part 3 deals with the measurement of turnover intentions, serving as the surrogate for turnover that was developed by Chen [22], using three issues, including: "I often think about leaving the job"; "I will not renew the contract when the current contract is due"; and "I am planning a job and life after leaving the job."

A 6-point Likert scale ranging from 1 for strongly dissatisfied (or disagree) to 6 for strongly satisfied (or agree) was used to measure the items of the first three parts.

Part 4 presents respondents' demographic information includeing age, gender, education level, marital status, wages, organization tenure and job position.

The construction engineers employed by Taiwanese engineering consulting firms were interviewed through a convenient sampling method. The self-administered questionnaires were distributed to the construction engineers after ensuring their willingness to take part in this survey. The data collection was conducted from March to May 2009. A total of 900 questionnaires were distributed; 763 usable samples were obtained after deleting any incomplete questionnaires, resulting in a response rate of $84.78 \%$.

The majority of respondents (87.29\%) ranged from 26 years old to 50 years old. Respondents with a university degree or above constituted $43.32 \%$ of the sample, and $35.24 \%$ were unmarried. Respondents' wages clustered at two levels: $47.12 \%$ were under NT $\$ 30,000$ per month and $52.88 \%$ above NT\$30.001 per month ( $\$ 1$ is roughly equivalent to NT\$33). With respect to length of service; $50.13 \%$ had been with the company less than 7 years and $49.87 \%$ longer than 7 years. Respondents with a professional engineer license accounted for $32.07 \%$ of the sample.

\section{Analysis}

The effects of job satisfaction and organizational commitment on turnover intentions were studied in a sample of construction engineers. Data analysis occurred in two stages.

The first stage explored the internal structure of the job satisfaction and organizational commitment using factor analysis. The second stage examined relationships between construction engineers' turnover intention and their perceptions of job satisfaction, organizational commitment and personal and work environment characteristics by logistic regression analysis.

Factor analysis, primary purpose of which is to define the underlying structure among the variables in the analysis, is a statistical approach that can be used to analyze interrelaships (correlations) among a large number of variables and to explain these variables in terms of their common underlying dimensions (factors). The objective is to find a way of condensing the information contained in a number of original variables into a smaller set of variates (factors) with minimal loss of information. By providing an empirical estimate of the
Table 1. Factor analyses of job satisfaction and organizational commitment.

\begin{tabular}{|l|c|c|c|c|}
\hline Factor & $\begin{array}{c}\text { Eigen } \\
\text { value }\end{array}$ & $\begin{array}{c}\text { Variance } \\
\text { explained (\%) }\end{array}$ & $\begin{array}{c}\text { Cronbach's } \\
\alpha\end{array}$ & $\begin{array}{c}\text { Factor } \\
\text { mean }\end{array}$ \\
\hline \multicolumn{5}{|c|}{ Job satisfaction } \\
\hline $\begin{array}{l}\text { Pay and promotion } \\
\text { satisfaction }\end{array}$ & 9.05 & 43.18 & .87 & 3.76 \\
\hline $\begin{array}{l}\text { Supervision } \\
\text { satisfaction }\end{array}$ & 1.87 & 7.49 & .84 & 3.65 \\
\hline $\begin{array}{l}\text { Job-itself } \\
\text { satisfaction }\end{array}$ & 1.19 & 3.51 & .78 & 4.35 \\
\hline $\begin{array}{l}\text { Self-achievement } \\
\text { satisfaction }\end{array}$ & 1.01 & 3.12 & .88 & 4.12 \\
\hline \multicolumn{5}{|c|}{ Organizational commitment } \\
\hline $\begin{array}{l}\text { Affective } \\
\text { commitment }\end{array}$ & 12.26 & 59.59 & .96 & 4.12 \\
\hline $\begin{array}{l}\text { Continuance } \\
\text { commitment }\end{array}$ & 1.13 & 3.63 & .87 & 4.34 \\
\hline
\end{tabular}

structure of the variables considered, factor analysis becomes an objective basis for creating summated scales [35, 38]. The Cronbach's $\alpha$, which can measure how well a set of variables or items measures a single, unidimensional latent construct, was calculated to test the internal reliability for each of the multi-item factors in our questionnaire [4, 28, 29].

Logistic regression (sometimes called the logistic model or logit model) is usually used for prediction of the probability of occurrence of an event by fitting data to a logistic curve. It is a generalized linear model used for binomial regression. Like many forms of regression analysis, it makes use of several predictor variables that may be either numerical or categorical $[2,5,10,36,42,45]$. Logistic regression analysis was undertaken in this study to determine the extent to which job satisfaction, organization commitment and individual characteristics variables predicted turnover intension.

\section{RESULTS}

Principal component factor analysis with a varimax rotation technique was used to generate the underlying factors of job satisfaction and organizational commitment. Using an eigenvalue greater than 1.0 as the criterion, the factor analyses suggests that a four-factor solution explained $57.34 \%$ total variance for job satisfaction and a two-factor solution explained $63.22 \%$ total variance for organizational commitment. The Cronbach's $\alpha$ values for all remaining factors are greater than 0.7 , indicating high reliability.

Table 1 summarizes the factor analysis results. The four job satisfaction factors are "job satisfaction," "pay and promotion satisfaction," "supervision satisfaction," and "self-achievement satisfaction." The two organizational commitment factors are "affective commitment," and "continuance commitment."

Logistic regression was applied to survival data in the health sciences, originally [45]. It can enable the researcher to use regression models to predict the probability of a particular 
Table 2. Result of binary logistic regression.

\begin{tabular}{|c|c|c|c|}
\hline Variable & Coefficient & s.e. & Odds ratio \\
\hline Age & -.206 & .304 & .814 \\
\hline Education & -.209 & .206 & .811 \\
\hline Salary & -.185 & .271 & .831 \\
\hline Seniority & -.253 & .240 & .777 \\
\hline License & .157 & .223 & 1.170 \\
\hline Marriage & .249 & .263 & 1.282 \\
\hline $\begin{array}{l}\text { Pay and promotion } \\
\text { satisfaction }\end{array}$ & $.544 * *$ & .216 & 1.722 \\
\hline Supervision satisfaction & -.183 & .138 & .833 \\
\hline Job-itself satisfaction & -.080 & .186 & .923 \\
\hline $\begin{array}{l}\text { Self-achievement } \\
\text { satisfaction }\end{array}$ & -.038 & .203 & .962 \\
\hline Affective commitment & $-1.117 * * *$ & .237 & .327 \\
\hline $\begin{array}{l}\text { Continuance } \\
\text { commitment }\end{array}$ & .339 & .211 & 1.403 \\
\hline Constant & 1.407 & .649 & 4.083 \\
\hline -2 Log-likelihood & & & 665.09 \\
\hline Chi-squared & & & 46.73 \\
\hline (d.f., p-value) & & & $(12,0.000)$ \\
\hline
\end{tabular}

Notes: Age: ' $<=36$ ' $=0,{ }^{\prime}>36$ ' $=1$;

Education : ' $<=$ university' $=0,{ }^{\prime}>$ university' $=1$;

Salary: ' $<=30,000 ’=0, '>30,000$ ' $=1$;

Seniority: ' $<=7$ years' $=0, '>7$ years' $=1$.

${ }^{* * *} p<0.01 ; * * p<0.05 ; * p<0.10$.

categorical response for a given set of explanatory variables. This logistic regression model is based on the odds ratio, which represents the probability of success compared with the probability of failure.

Before conducting the logistic regression analysis, the mean of the three turnover intention items was transformed into a binary category with a value of 1 if greater than 3.5 and with a value of 0 otherwise. The binary turnover intention is used as the dependent variable.

Table 2 reports the results of logistic regression analysis, together with the marginal effects calculated holding all other variables at their sample mean. A test of the full model with all predicators against a constant-only model is statistically reliable, where $\chi^{2}=46.73, p<0.001$. "Job satisfaction" and "normative commitment" are significant at the 5\% level, indicating their determining effects on turnover intentions. With regards to the personal characteristics variables, none of them are significant at the $5 \%$ level.

\section{CONCLUSIONS AND LIMITATIONS}

\section{Conclusions}

The quality of the national infrastructures and the construction projects are the important basis to get the high level of living of nationals. An engineering consultant company needs excellent engineers to take and to maintain the quality of the project and competitive edges in the engineering industry. If organizations are to effectively manage turnover of employees, they need to understand how to influence the reasons employees think about quitting [84]. A simple model of turnover intension prediction was developed and generally supported by a logistic regression analysis. The conclusions provided are listed below:

First, based on the knowledge-based, expertise-intensive and experience-oriented nature of the work environment characteristics, the real cost of the construction engineer turnover is very expensive, and more engineering companies are beginning to realize that this drain upon the resources and competitive capability of organizations minimized or eliminated in the competition-intensive engineering consultant service industry. Management interventions in the process could reduce turnover intention and stifle the motivation to quit.

Second, job satisfaction is divided into four separate factors: "job satisfaction," "pay and promotion satisfaction," "supervision satisfaction," and "self-achievement satisfaction." The organizational commitment factors are separated into two factors: "affective commitment" and "continuance commitment."

Third, the present model is designed to fill the gap of previous research in construction engineer turnover study. The results from our analysis revealed that "pay and promotion satisfaction" and "affective commitment" are major factors affecting construction engineers' turnover intentions. It appears to be related to the individual's perception of past and present aspects of one's organization.

Fourth, this suggests that enhancements in job satisfaction and organizational commitment can be expected to reduce construction engineers' intentions to quit. The "pay and promotion satisfaction" and "affective commitment" factors significantly influence the intention to leave the construction engineers, but the other factors are not significant. It is also shown that detailed analysis is needed to discover the specific phenomenon in different industries.

Finally, the model proposed in the study seems to be extendable to other types of organizations, and therefore appears to deserve additional testing and refinement by follow-up researchers.

\section{Limitations}

The following should be taken into consideration when interpreting the present findings:

First, Logistic regression analysis permits only weak evaluation of causal hypotheses. Logistic techniques do not prove causality. Rather, users of the logistic regression assume causality rather than prove causality [48]. Present findings, based on correlation data, do not allow strong causal interpretations.

Second, overestimation may have occurred in relations among satisfaction, commitment and intention/cognitions due to shared method variance and social desirability [30].

Third, the longitudinal study may be an appropriate method 
to examine causal relationships among the turnover intentions can be considered in further studies [84]. Mobely et al. [67] suggest that the predictive power of intent to leave statements should decay as the time period of the prediction increases. Hom and Griffeth [44] also analyzed the lag effect on turnover.

Finally, only the most often-cited characteristics among turnover were investigated here, precluding more powerful and complex investigation of the turnover process.

\section{REFERENCES}

1. Adams, A. and Bond, S., "Hospital nurses' job satisfaction, individual and organizational characteristics," Journal of Advanced Nursing, Vol. 32, No. 3, pp. 536-543 (2000).

2. Agresti, A., Categorical Data Analysis, Wiley-Interscience, New York (2002).

3. Ajzen, I. and Fishbein, M., Understanding Attitudes and Predicting Social Behavior, Prentice Hall, Englewood Cliffs, NJ (1980).

4. Allen, M. J. and Yen, W. M., Introduction to Measurement Theory, Long Grove, IL: Waveland Press (2002).

5. Amemiya, T., Advanced Econometrics, Harvard University Press, Cambridge, MA (1985).

6. Argyris, C. "Personality and organization theory revisited," Administrative Science Quarterly, Vol. 18, pp. 141-167 (1973).

7. Arnold, H. J. and Feldman, D. C., "A multivariate analysis of the determinants of job turnover," Journal of Applied Psychology, Vol. 67, pp. 350-360 (1982).

8. Arvey, R. D., Bouchard, T, J., Segal, N. L., and Abraham, L. M., "Job satisfaction: Environmental and genetic components," Journal of Applied Psychology, Vol. 74, No. 2, pp. 187-192 (1989).

9. Association of Consulting Engineers, Association of Consulting Engineers Who's Who and Year Book (Authorised List of Members), Association of Consulting Engineers, Vol. XLIV (1991).

10. Balakrishnan, N., Handbook of the Logistic Distribution, Marcel Dekker, Inc. (1991).

11. Bateman, T. S. and Strasser, S., "A longitudinal analysis of the antecedents of organizational commitment," Academy of Management Journal, Vol. 27, pp. 95-112 (1984).

12. Begley, T. M. and Czajka, J. M., "Panel analysis of the moderating effects of commitment on job satisfaction, intent to quit, and health following organizational change," Journal of Applied Psychology, Vol. 78, No. 4, pp. 552-556 (1993).

13. Bem, D. J., "Self-perception: an alternative interpretation of cognitive dissonance," Psychological Review, Vol. 74, pp. 183-200 (1967).

14. Bluedorn, A. C., A Causal Model of Turnover in Organizations, Unpublished Ph. D. Dissertation, University of Iowa (1976).

15. Bluedorn, A. C., "A taxonomy of turnover," The Academy of Management Review, Vol. 3, No. 3, pp. 647-651 (1978).

16. Bluedorn, A. C., "A unified model of turnover from organizations," Human Relations, Vol. 35, No. 2, pp. 135-153 (1982).

17. Borcherding, J. D. and Oglesby, C. H., "Construction productivity and job satisfaction," Journal of the Construction Division, ASCE, Vol. 100, No. 3, pp. 413-431 (1974).

18. Bowen, P., Cattell, K., Distiller, G., and Edwards, P. J., "Job satisfaction of South African quantity surveyors: an empirical study," Construction Management and Economics, Vol. 26, No. 7, pp. 765-780 (2008).

19. Bowey, A. M., A Guide to Manpower Planning, Macmillan, London (1974).

20. Buchanan, B., "Building organizational commitment: The socialization of managers in work organizations," Administrative Science Quarterly, Vol. 19, No. 4, pp. 533-546 (1974).

21. Burton, J. F. and Parker, J. E., "Interindustry variations in voluntary labor mobility," Industrial and Lobor Relations Review, Vol. 22, pp. 199-216
(1969).

22. Chen, J. F., "Job satisfaction, organizational commitment, and flight attendants' turnover intentions: a note," Journal of Air Transport Management, Vol. 12, pp. 274-276 (2006).

23. Chow, L. K. and Thomas Ng, S., "A fuzzy gap analysis model for evaluating the performance of engineering consultants," Automation in Construction, Vol. 16, No. 4, pp. 425-435 (2007)

24. Clegg, C. W., "Psychology of employee lateness, absence, and turnover: A methodological critique and empirical study," Journal of Applied Psychology, Vol. 68, pp. 88-101 (1983).

25. Clowes, G. A., "A dynamic model for the analysis of labor turnover," Journal of the Royal Statistical Society A, Vol. 122, pp. 242-256 (1972).

26. Cooley, M. S., "Selecting the right consultants," HR Magazine, Vol. 39, No. 8, pp. 100-103 (1994).

27. Cornoy, G. Y., “The personnel turnover concept: A reappraisal,” Public Administration Review, Vol. 17, pp. 247-256 (1957).

28. Cronbach, L. J., "Coefficient alpha and the internal structure of tests," Psychometrika, Vol. 16, No. 3, pp. 297-334 (1951).

29. Cronbach, L. J. and Shavelson, R. J., "My current thoughts on coefficient alpha and successor procedures," Educational and Psychological Measurement, Vol. 64, No. 3, pp. 391-418 (2004).

30. Crowne, D. P. and Marlowe, D., The Approval Motive: Studies in Evaluative Dependence, Wiley, New York (1964).

31. Dabke, S., Salem, O., Genaidy, A., and Daraiseh, N., "Job Satisfaction of Women in Construction Trades," Journal of Construction Engineering and Management, ASCE, Vol. 134, No. 3, pp. 205-216 (2008).

32. Dougherty, T. W., Bluedom, A. C., and Keon, T. L., "Precursors of employee turnover: A multi-sample causal analysis," Journal of Occupational Behaviour, Vol. 6, pp. 259-271 (1985).

33. Farris, G. F., “A predictive study of turnover," Personnel Psychology, Vol. 24, pp. 311-328 (1971).

34. Goodman, P. S., Salipante, P., and Paransky, H., "Hiring, training, and retaining the hardcone unemployed: A selective review," Journal of Applied Psychology, Vol. 58, pp. 23-33 (1973).

35. Gorsuch, R. L., Factor Analysis, Lawrence Erlbaum, Hillsdale, NJ (1983).

36. Greene, W. H., Econometric Analysis, fifth edition, Prentice Hall, Englewood Cliffs, NJ (2003).

37. Hackett, D., Bycio, P., and Hausdorf, P., "Further assessments of Meyer and Allen's (1991) three component model of organizational commitment," Journal of Applied Psychology, Vol. 79, pp. 15-24 (1994).

38. Hair, J. F., Black, W. C., Babin, B. J., Anderson, R. E., and Tatham, R. L., Multivariate Data Analysis, 6th Eds., Person Education In., NJ (2006).

39. Hancer, M. and George, R. T., "Job satisfaction of restaurant employees: an empirical investigation using the Minnesota Satisfaction Questionnaire," Journal of Hospitality \& Tourism Research, Vol. 27, No. 1, pp. 85-100 (2003).

40. Hattan, D. E. and Lalani, N., "Selecting the right consultant team," Institute of Transportation Engineering Journal, Vol. 67, No. 9, pp. 40-46 (1997).

41. Heneman, H. G. and Schwab, D. P., "Pay satisfaction: Its multidimensional nature and measurement," International Journal of Psychology, Vol. 20, No. 1, pp. 129-141 (1985).

42. Hilbe, J. M., Logistic Regression Models, Chapman \& Hall/CRC Press, Boca Raton, FL (2009).

43. Hollenbeck, J. R. and Williams, C. R., "Turnover functionality versus turnover frequency: A note on work attitudes and organizational effectiveness," Journal of Applied Psychology, Vol. 71, pp. 606-611 (1986).

44. Hom, P. W. and Griffeth, R. W., "Structural equations modeling test of a turnover theory: Cross-sectional and longitudinal analyses," Journal of Applied Psychology, Vol. 76, pp. 350-366 (1991).

45. Hosmer, D. W. and Lemeshow, S., Applied Logistic Regression, 2nd ed., Wiley, New York (2000).

46. Hrebiniak, L. C. and Allutto, J. A., "Personal and role-related factors in the development of organizational commitment," Administrative Science Quarterly, Vol. 18, pp. 555-572 (1973). 
47. Huang, C. F., Yang, L. R., and Ou, Y. H., "A study on the relationship between job stress and job satisfaction of construction engineers," Proceedings of CSCE 2007 Annual General Meeting \& Conference, Yellowknife, Canada (2007).

48. James, L R., Muliak, S. A., and Brett, J. M., Causal Analysis: Assumptions, Models, and Data, Sage Publications, Beverly Hills (1982).

49. Jaros, S., “An assessment of Meyer and Allen's (1991) three-component model of organizational commitment and turnover intentions," Journal of Vocational Behavior, Vol. 51, pp. 319-337 (1997).

50. Kantor, R. M., "Commitment and social organization: a study of commitment mechanisms in utopian communities," American Sociological Reciew, Vol. 33, pp. 499-517 (1968).

51. Kasma, D. R., "Consultant selection," Journal of Management in Engineering, ASCE, Vol. 3, No. 4, pp. 288-296 (1987).

52. Katzell, R. A., Korman, A. K., and Levine, E. L., Overview Study of the Dynamics of Worker Job Mobility, Social and Rehabilitative Services, U.S. Department of Health, Education, and Welfare, Washington, D.C. (1971)

53. Knowles, M. C., "A review of tabor turnover research," Personnel Practice Bulletin, Vol. 20, pp. 5-37 (1964).

54. Lawler, E. E., Motivation in Work Organizations, Brooks/Cole, Monterey (1973).

55. Lefkowitz, J., "Personnel turnover,” In: Abt, L. E. and Reiss, B. F. (Eds.), Progress in Clinical Psychology, Grune and Stratton, New York, pp. 69-90 (1971).

56. Leung, M. Y. and Chan, H. K. L., "Antecedents of commitment in construction management," Construction Management and Economics, Vol 25, No. 2, pp. 113-127 (2007).

57. Locke, E. A., "Toward a theory of task motivation and incentives," Organizational Behavior and Human Performance, Vol. 3, pp. 157-189 (1968).

58. Locke, E. A., "The nature and causes of job satisfaction," In: Dunnette, M. D. (Ed.), Handbook of Industrial and Organizational Psychology, Rand McNally, Chicago, pp. 1319-1328 (1976).

59. Long, J. R., Labor Turnover under Full Employment, Research Board, Faculty of Commerce and Social Science, University of Birmingham, Birmingham (1951).

60. Lyons, T. F., Nursing Altitudes and Turnover, Industrial Relations Center, Iowa State University, Ames (1968).

61. Maertz, C. P., Stevens, M. J., and Campion, M. A., "A turnover model for the Mexican maquiladoras," Journal of Vocational Behavior, Vol. 63, pp. 111-135 (2003).

62. March. J. G. and Simon, H. A., Organizations, Wiley, New York (1958).

63. Marsh, R. M. and Manari, H., "Organizational commitment and turnover: A prediction study,” Administration Science Quarterly, Vol. 22, pp. 57-75 (1977).

64. Martin, T. N., A Structural Analysis of the Determinants of Voluntary Turnover, Unpublished Ph.D. Dissertation, University of Iowa (1977).

65. Mathieu, J. E. and Farr, J. L., "Further evidence for the discriminant validity of measures of organizational commitment, job involvement, and job satisfaction," Journal of Applied Psychology, Vol. 76, No. 1, pp. 127 133 (1991)

66. Meyer, J. P. and Allen, N. J., Commitment in the Workplace: Theory, Research and Application, Sage Publications, Thousand Oaks (1997).

67. Mobely, W. H., Griffeth, R. W., Hand, H. H., and Meglino, B. M., "Review and conceprual analysis of the employee turnover process," Psychological Bulletin, Vol. 86, pp. 493-522 (1979).

68. Mowday, R. T., Koberg, C. S., and McArthur, A. W., "The psychology of the withdrawal process: a cross-validational test of Mobely's intermediate linkages model of turnover in two samples," Academy of Management Journal, Vol. 27, pp. 79-94 (1984).

69. Mowday, R. T., Porter, L. W., and Steers, R. M., Employee-Organization Linkages, Academic Press, New York (1982).

70. Mowday, R. T., Steers, R. M., and Porter, L. W., "The measurement of organizational commitment," Journal of Vocational Behavior, Vol. 14, pp. 224-247 (1979)
71. Mueller, C. W. and McCloskey, J. C., "Nurses' job satisfaction: a proposed measure," Nursing Research, Vol. 39, pp. 113-117 (1990).

72. O'Reliiy, C. A. III and Caldwell, D. F., "The commitment and job tenure of new employees: some evidence of post decisional justification," $\mathrm{Ad}$ ministration Science Quarterly, Vol. 26, pp. 597-616 (1981).

73. Oakland, J. S. and Aldridge, A. J., "Quality management in civil and structural engineering consulting," International Journal of Quality \& Reliability Management, Vol. 12, No. 3, pp. 32-48 (1995).

74. Pencavel, J. H., An Analysis of the Quit Rates in American Manufacturing Industry, Industrial Relations Section, Department of Economics, Princeton University, Princeton (1970).

75. Pettman, B. O., "Some factors innuencing labor turnover: A review of research literature," Industrial Relations, Vol. 4, pp. 43-61 (1973).

76. Porter, L. W., "The etiology of organizational commitment: a longitudinal study of initial stages of employee-organization relationships," unpublished manuscript (1968).

77. Porter, L. W., Crampon, W. J., and Smith, F. J., "Organizational commitment and managerial turnover: A longitudinal study," Organizational Behavior and Human Performance, Vol. 15, No. 1, pp. 87-98 (1976).

78. Porter, L. W. and Steers, R. M., "Organizational, work, and personal factors in employee turnover and absenteeism," Psychological Bulletin, Vol. 80, pp. 151-176 (1973).

79. Porter, L. W., Steers, R. M., Mowday, R. T., and Boulian, P. V., “Organizational commitment, job satisfaction, and turnover among psychiatric technicians," Journal of Applied Psychology, Vol. 59, No. 5, pp. 603-609 (1974).

80. Price, J. L. and Mueller, C. W., "A Causal Model of Turnover for Nurses," Academy of Management Journal, Vol. 24, No. 3, pp. 543-565 (1981).

81. Price, J. L. and Mueller, C. W., "Absenteeism and turnover of hospital employees,” In: Bacharach, S. B. (Ed.), Monographs in Organizational Behavior and Industrial Relations, JAI Press, Greenwich, CON (1986).

82. Rosse, J. G. and Hulin, C. L., "Adaption to work: An analysis of employee health, withdrawal, and change," Organizational Behavior and Human Decision Processes, Vol. 36, pp. 324-347 (1985).

83. Rowings, J. E., Federle, M. O., and Birkland, S. A., "Characteristics of the craft workforce," Journal of Construction Engineering and Management, ASCE, Vol. 122, No. 1, pp. 83-90 (1996).

84. Sager, J. K., Griffeth, R. W., and Hom, P. W., “A comparison of structural models representing turnover cognitions," Journal of Vocational Behavior, Vol. 53, pp. 254-273 (1998)

85. Salancik, G. R. and Pfeffer, J. A., "A social information processing approach to job attitudes and task design," Administrative Science Quarterly, Vol. 23, pp. 224-235 (1978).

86. Samson, D. and Parker, R., "Service quality: the gap in the Australian consulting engineering industry," International Journal of Quality and \& Reliability Management, Vol. 11, No. 7, pp. 60-76 (1994).

87. Schein, E., "Organizational socialization and the profession of management," Industrial Management Review, Vol. 9, pp. 1-16 (1968).

88. Schoenherr, R. A. and Greeley, A. M. "Role commitment process and the American Catholic priesthood," American Sociological Review, Vol. 39, pp. 407-426 (1974)

89. Schuh, A. J., "The predictability of employee turnover: A review of the literature," Personnel Psychology, Vol. 20, pp. 133-152 (1967).

90. Sheldon, M. E., "Investments and involvement as mechanisms producing commitment to the organization," Administration Science Quarterly, Vol. 16, pp. 143-150 (1971).

91. Shore, L. M. and Martin, H. J., "Job satisfaction and organizational commitment in relation to work performance and turnover intentions," $\mathrm{Hu}$ man Relations, Vol. 42, No. 7, pp. 625-638 (1989).

92. Stamps, P. L. and Peidmont, E. B., Nurses and Work Satisfaction, Health Administration Press Perspectives, Ann Arbor, Michigan (1986).

93. Stoikov, V. and Raimon, R. L., "Determinants of differences in the quit rate among industries," American Economic Review, Vol. 58, pp. 12831298 (1968).

94. Tett, R. P. and Meyer, J. P., "Job satisfaction, organizational commitment, turnover intention: path analysis based on meta-analytic findings," Per- 
sonnel Psychology, Vol. 46, pp. 259-293 (1993).

95. Traynor, M. and Wade, B., "The development of a measure of job satisfaction for use in monitoring the morale of community nurses in four Trusts," Journal of Advanced Nursing, Vol. 18, pp. 127-136 (1993).

96. Vroom, V. H., Work and Motivation, Wiley, New York (1964).

97. Waters, L. K., Roach, D., and Waters, C. W., "Estimates of future tenure, satisfaction, and biographical variables as predictors of termination," Personnel Psychology, Vol. 29, pp. 57-60 (1976).

98. Weiss, D. J., Dawis, R. V., England, G. W., and Lofquist, L. H., Manual for the Minnesota Satisfaction Questionnaire, Industrial Relations Center, University of Minnesota, Minneapolis (1967).

99. Werbel, J. D. and Gould, S., "A comparison of the relationship of commitment to turnover in recent hires and tenured employees," Journal of Applied Psychology, Vol. 9, No. 4, pp. 687-690 (1984).

100. Williams, L. J. and Hazer, J. T., "Antecedents and consequences of job satisfaction and organizational commitment in turnover models: a reanalysis using latent variable structural equation methods," Journal of Applied Psychology, Vol. 71, pp. 219-231 (1986). 